\title{
En los intersticios de las imágenes
}

\author{
Los deseos concebidos | Cristián Sánchez | 1982
}

Esteban Radiszcz"

Universidad de Chile

Recibido: 5 de enero 2018; aceptado: 6 de abril 2018

\begin{abstract}
Resumen
Múltiples objeciones impiden refrendar la muy usual analogía, tan frecuentemente sostenida en psicoanálisis y teoría cinematográfica, entre el cine y el sueño. Ella misma dificulta observar la más precisa dimensión onírica del trabajo del film, cuyas operaciones metamórficas (Benjamin) comparten expedientes con el trabajo del sueño, sin por ello hacer del cine un asunto onírico. De hecho, contraria a la tiranía hipnótica de la industria cultural cinematográfica, la dimensión onírica del film descentra la imagen que, diseminada conforme a su desvío entre los intersticios de las imágenes, disloca la uniformidad de la imagen ofrecida para su consumo por la Fábrica de sueños (Ehrenburg). Los deseos concebidos del realizador chileno Cristián Sánchez da precisamente cuenta de esta subversión onírica que, tanto por su diégesis como por su tratamiento de las imágenes, por las imágenes y entre las imágenes, se resiste a hacer del film "tan sólo un sueño".
\end{abstract}

Palabras Clave: Sueño | Cine | Cristián Sánchez | Hipnosis | Trabajo del film

Los deseos concebidos

Abstract

Multiple objections frequently stated by psychoanalysts and film theorists prevent to support the analogy between cinema and dream. This analogy limits the observation of the most precise oneiric dimension of the film-work (Kuntzel), whose metamorphic mechanisms (Benjamin) share files with the dream without making the film an oneiric matter. In fact, contrary to the hypnotic tyranny of the film cultural industry, the film's oneiric dimension decentralises the image that, disseminated according to its deviation between the interstices of the images, dislocates the uniformity of the image offered by the Dream Factory (Ehrenburg). The Chilean filmmaker Cristián Sanchez's film Los deseos concebidos shows precisely this oneiric subversion that, as much by its diegesis as by its treatment of the images, by the images and among the images, resists to make of the film "only a dream".

Key Words: Dream | Cinema | Cristián Sánchez | Hypnosis | Film-work

\section{Prefacio: un falso recuerdo}

En un artículo, publicado hace más de doce años (Radiszcz, 2005), tuvimos la oportunidad de detenernos en $U n$ Chien Andalou (Buñuel, 1929) para explorar la producción del "inconsciente óptico", respecto del cual Walter Benjamin (1955[1939]) había interrogado el lugar central de las operaciones metamórficas de la cámara para el cine. En aquel entonces, interesaba indicar que la composición del espacio cinematográfico no podía de ningún modo reducirse a la sola visión de imágenes o a la percepción de una sucesión de ellas. De hecho, sosteníamos, resulta imprescindible no descuidar la contribución decisiva del tratamiento fílmico que, efectuado en las imágenes, con las imágenes, por las imágenes y, sobre todo, entre las imágenes, participa en la configuración del campo escópico donde la división del sujeto resulta de su encuentro con la mirada. ${ }^{1}$

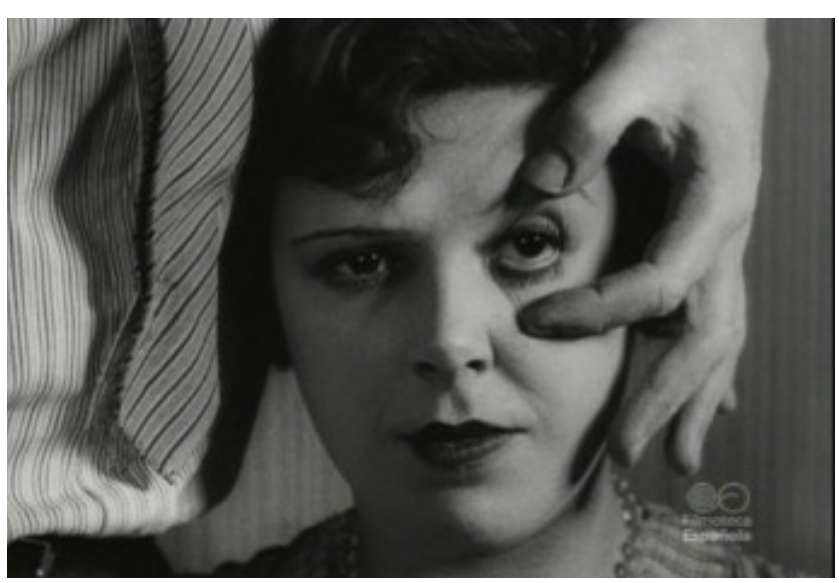

L. Buñuel, Un chien Andalou, 1929.

En tal sentido, el prólogo y el epílogo del pequeño film de Luis Buñuel muestran, de manera para nosotros magistral, la incidencia fundamental que las operaciones

radiszcz@gmail.com 
fílmicas de corte y de montaje tienen sobre la dimensión escópica del vector subjetivo en el plano geometral. Mediante articulaciones diversas obtenidas según modalidades variables, estas operaciones suscitarían una escisión del ojo fílmico que, repartido entre la cámara y el espectador, preside el despliegue de un espacio cinematográfico donde adviene el objeto escópico que allí circula no tanto en la imagen, sino más bien entre las imágenes. Así, la verdadera materia fílmica no debería ser buscada en la visibilidad entregada por las imágenes, sino ser encontrada en lo invisible de un real hallado entre los intersticios de las imágenes, cuya metáfora nos ha sido ofrecida en Un perro andaluz mediante el humor vítreo que brota del ojo cortado por la acción del propio realizador.

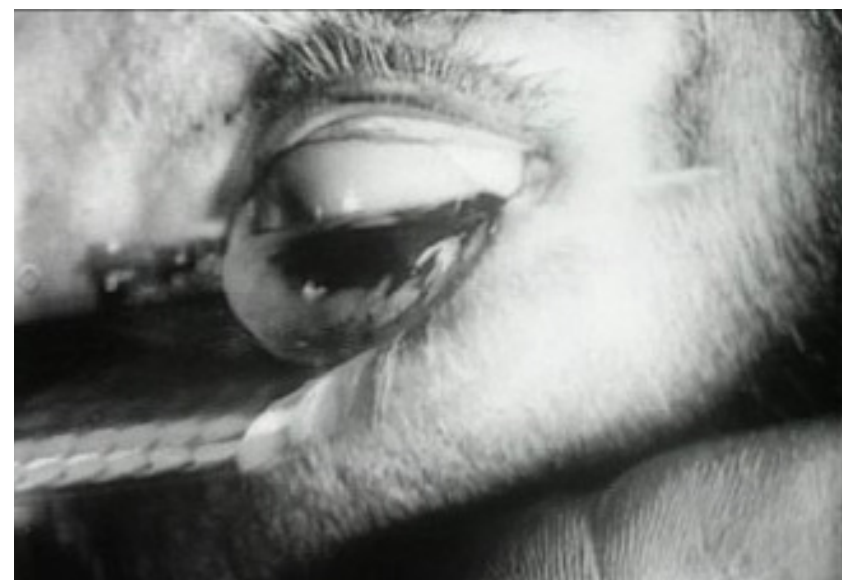

L. Buñuel, Un chien andalou, 1929

De este modo, la presente contribución cuenta prolongar aquellas consideraciones en función de una pista que, dejada entonces suspendida en una breve indicación de algunas pocas líneas, pretende problematizar la relación entre cine y sueño. Ella es, sin duda, una asociación muchas veces formulada, particularmente entre los psicoanalistas ${ }^{2}$ aunque no únicamente por ellos. ${ }^{3}$ Sin embargo, se trata de una conexión que, en razón de la masividad casi ingenua con la cual es frecuentemente - aún en nuestros días - sostenida, ${ }^{4}$ resulta a tal punto sospechosa que suscitó en mí un curioso recuerdo, cuyo contenido procedo a confiarles.

En efecto, tuve el recuerdo, claro y preciso, de haber leído (o escuchado) la más contundente afirmación que, sostenida por un reconocido realizador, formulaba la absoluta imposibilidad de filmar un sueño. El problema es que no tenía la menor idea de iquién habría podido decir algo parecido! Recorrí los textos. Releí teóricos e historiadores del cine. Busqué entre los directores. Pregunté a mis amigos cinéfilos. Interrogué a especialistas.
Pero no encontré nada. ¿ ¿Habría yo, entonces, soñado aquella afirmación? ¿Habría, acaso, tenido un sueño sobre la imposibilidad de filmar un sueño? ¿Se trataba más bien de un recuerdo encubridor construido a partir de la firme oposición freudiana ante las tentativas de Samuel Goldwyn para llevar el psicoanálisis a la pantalla hollywoodense (cf. Gay, 1988, pp. 506-507) ? ¿ O, quizás, era un falso recuerdo edificado sobre la aún más enérgica objeción de Freud - Dumm dinge [sandeces], habría exclamado (1925, p. 68) - frente a la contribución de Karl Abraham y Hans Sachs (cf. Farges, 1975, pp. 90-91) en la redacción del guión de Los misterios de un alma rodado, en 1926, por Pabst ? ¿Era, así, asunto, en aquel llamativo recuerdo, de la "cinefobia" freudiana (Michel, 2010-11) que, a favor de mi sospecha, habría yo convenientemente atribuido al conjunto de los sueños y de las películas?

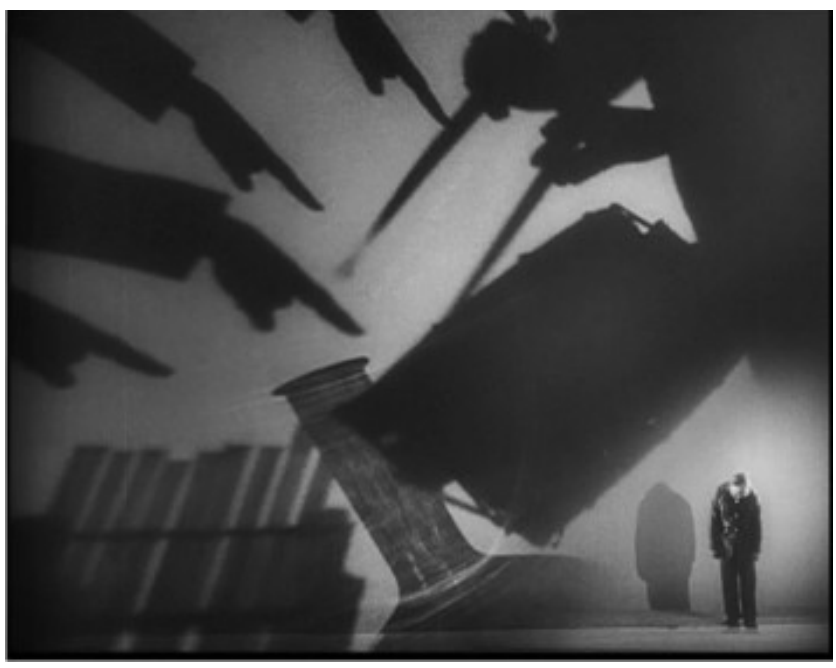

G. W. Pabst, Gebeimnisse einer Seele, 1926

\section{El sueño en el cine}

En todo caso, que se trate de una ficción onírica o de una fabulación mnémica, dicho falso recuerdo no parece del todo extraviado. No es que no hayan sueños filmados. Basta pensar en Spellboum de Hitchcock (1945), Los olvidados de Buñuel (1950) o Fresas Salvajes de Bergman (1957) De hecho, como lo indica Lydia Marinelli (2006), desde sus inicios el cine no ha sido avaro para llevar numerosos sueños a la pantalla. Fue, por supuesto, el caso de Georges Méliès en El sueño del profesor de ballet (1903) o en El sueño del relojero (1904), así como también aquel de Edwin S. Porter en Life of an American Fireman (1903) o en The Dream of a Rarebit Fiend (1906). 


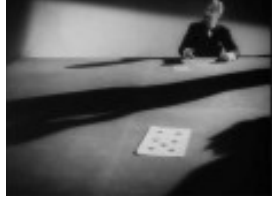

A. Hitchcock, Spellbound, 1947 L .Buñuel, Les oubliés, 1950

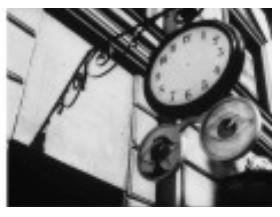

I. Bergman, Smultronstället, 1957

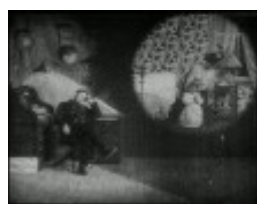

S. Porter, Life of an American Fireman, 1903 Georges Méliès, Le rêve de l'horloger, 1904

Sin embargo, resultaría bastante abusivo afirmar que soñamos al ver un sueño filmado y aún más abusivo sostener, como se lo ha hecho, que ver una película no sería, en el fondo, nada distinto de tener un sueño o que soñar no sería otra cosa que ver cine en privado. Para contrariar tales ideas, sería suficiente con realizar el mismo tipo de ejercicio que Wittgenstein (1953) tenía el hábito de hacer para distinguir experiencias según las particularidades de los juegos de lenguaje concernidos en cada caso y que, justamente, hizo a propósito del acto de soñar para subrayar sus diferencias con otras acciones, particularmente aquellas de recordar, dormir o, incluso, ver (Wittgenstein, 1980).

Ciertamente, en una película, el sueño puede ser un material de trabajo, una fuente de imágenes, un recurso estético, un componente diegético, un operador semántico, una dislocación, una cesura, un ardid, un enigma, un capricho... Un film puede darle un importante lugar al sueño, pero el sueño de una película, aunque sea construido con el más fino dominio de los expedientes oníricos identificados por Freud (1900), no por ello es menos un asunto estrictamente fílmico. No se trata en absoluto de un sueño, sino de un sueño filmado, es decir, de un simulacro o de un artificio puesto al servicio del film. Del mismo modo, soñar con una película no tiene nada de propiamente fílmico, pues ante todo es un asunto propiamente onírico. Porque si el sueño se sirve de un film, ello siempre puede ser una indicación de que el soñante, como se dice, se pasa películas o que hace toda una teleserie. Una película soñada no es un film, sino una película al servicio del sueño.

De hecho, resulta problemático defender un parentesco fundamental entre el sueño y el cine en función de su supuesta semejanza. Que ambos tengan que ver con imágenes o con articulaciones de imágenes, no parece ser razón suficiente como para establecer una relación estricta entre ellos. Este tipo de analogía precipitada no sólo olvida que nunca nadie ha visto un sueño hecho por otro, pues de éste siempre sólo se tiene el relato. Pero, sobre todo, la analogía se sirve de la manera más banal de la expresión demasiado común según la cual el cine sería una "fábrica de sueños"; y lo hace, además, sin saber nada sobre la historia de esta fórmula. En todo caso, no hay nada muy original en reunir películas y sueños, toda vez que se trata de una idea tan antigua como el cine mismo. Basta pensar en los precoces propósitos de Jean Epstein (1947) o de René Clair (1951).

La expresión "fábrica de sueños” no es ajena a esta conexión, la cual ya era común en los años '30 cuando Ilya Ehrenburg (1931) la hizo famosa por su libro sobre la industria cinematográfica norteamericana. Sin embargo, Ehrenburg no refiere la fórmula para decir que las películas sean como los sueños ni que el cine fabrique sueños, sino para indicar que, al contrario, la industria cinematográfica, Hollywood en la ocasión, pretende invadir los sueños, homogeneizarlos para mejor controlarlos, emplazar un único “sueño” en lugar de todos los sueños: en una palabra, eliminar el sueño. "La gente - habría dicho Adolph Zukor, el creador de Paramount- también quiere soñar. Necesitan urgentemente que alguien les permita ver sueños hermosos. Y eso es lo que haremos: fabricarles sueños hermosos, sueños en serie, divertidos sueños a precio de ganga” (Ehrenburg, 1931, p. 25).

\section{La hipnosis contra el sueño}

En vez de sostener una relación entre el cine y el sueño, Raymond Bellour (2009) ha propuesto vincular el cine con la hipnosis. Pero esto es, justamente, lo que la perspectiva hollywoodense cuenta efectuar para eliminar los sueños mediante la pantalla: movilizar la hipnosis contra el sueño, conjurar la subversión onírica a través de la dominación hipnótica. ${ }^{6}$ Según William H. Hays, el primer director de la todopoderosa Motion Picture Association of Producers and Distributors of America (el sindicato de productores y distribuidores de cine norteamericanos) y el flamante creador del conocido Código Hays de Hollywood, era imperativo apropiarse de las pantallas para magnetizar a cada uno de los espectador que duerme en las salas oscuras de aquí y de allá. “Tenemos que saber transmitirles nuestra poesía - pensaba Hays -, la poesía del ideal y el dólar, la poesía de la lucha por el éxito: ésa que enseña que los poderosos mandan y los débiles trabajan. Es fácil programar el día que tendrá cada cual: ¡quédate junto al torno!, ¡teclea en la máquina de escri- 
bir!, ¡suma esas columnas de cifras! Pero eso no basta: necesitamos programarles también los sueños. Conseguir que sean conscientes ciudadanos de los Estados Unidos hasta en los sueños" (Ehrenbourg, 1931, pp. 59-60). Y es, precisamente, este poder hipnótico del cine aquello que también ha convocado la fascinación de los grandes dictadores: Hitler, Stalin, Pinochet y Kim Jong-il.

Sin embargo, el cine no es únicamente hipnosis. De hecho, el pleno imperio de ésta última sólo ocurre cuando los films se encuentran al extremo convertidos en pura "industria cultural” (Adorno \& Horkheimer, 1947[1944]). En oposición a ello, numerosas películas cuentan revertir abiertamente dicha empresa, mientras que variados directores proceden, de hecho, según la dirección inversa y movilizan el sueño contra la hipnosis para subvertir la sugestión del film. De este modo, las películas no estarían por entero privadas de algún vínculo con el sueño: si el cine puede imponerse como hipnosis al sueño, entonces ninguna película está exenta de albergar una dimensión onírica. Sería, ciertamente, esta precisa dimensión la que impulsa a aquellos "otros" films a contrariar el efecto-hipnosis de la fábrica cinematográfica.

Habría, entonces, una eventual relación entre sueño y cine. Pero ella no se encuentra a nivel de las imágenes, sino en el plano del destino de las imágenes (Rancière, 2003). Si la industria de Zukor, Goldwyn, Hugenberg, Eastman y los hermanos Warner no pretende dejar ningún lugar al sueño y, conforme a ello, moviliza la imagen contra la imagen para aniquilar la subversión onírica de las imágenes; del otro lado, habría un "otro" cine que no sustituye la imagen por otra imagen, sino que trata las imágenes para pertubar la imagen en los intersticios de las imágenes. En otras palabras, ningún paralelo entre el sueño y el cine podría hacer la economía de los procesos mediante los cuales tanto el uno como el otro tratan las imágenes. Ello significa que, si existe algún vínculo entre ellos, éste sólo puede ser captado por la posible relación entre dos formas de trabajo similares, aunque distintas: el trabajo del film y el trabajo del sueño.

Añadamos de inmediato otra reserva: el cine no puede simular el sueño, servirse de los procedimientos del trabajo del sueño, para hacer una película al modo en que se hace un sueño. No porque, en Mubolland Drive (2001), Lynch dé cuenta de una pericia casi freudiana para componer un film tan fiel a los expedientes del trabajo del sueño (Letzner \& Ross, 2005), habría que por ello concluir que la analogía entre el sueño y el cine pudise también hacerse en otros niveles. No olvidemos que esta película contiene, para su director, una crítica muy aguda hacia la industria cinematográfica de Hollywood. Si él utiliza el trabajo de sueño para construir su película, ello no es porque el film sea un sueño, sino porque pretende, a través de aquel trabajo de puesta en imágenes, perturbar la imagen única de la dominación hollywoodense (Morel, 2011).? Lynch sigue aquí a Ehrenburg.

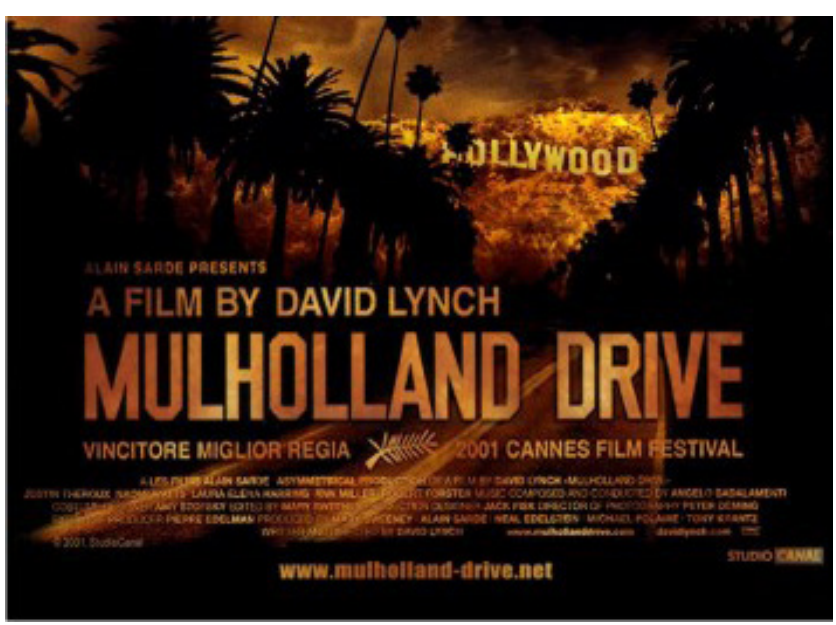

D. Lynch, Muholland Drive, 2001

Más precisamente, entonces, se trataría a nuestro juicio de aproximar los procedimientos tanto del trabajo del sueño como del trabajo del film, sin confundir el uno con el otro, al igual que Thierry Kuntzel (19721975) pudo hacerlo en sus dos meritorios escritos que, publicados hace más de 40 años, no han realmente tenido prolongación en lo sucesivo. ${ }^{8}$ Un trabajo del film que, como el trabajo del sueño, trata las imágenes para hacer advenir, entre sus intersticios, un real capaz de subvertir las apariencias.

\section{Los deseos concebidos}

Los deseos concebidos ${ }^{9}$ de Cristián Sánchez pertenece a aquel cine cuyo trabajo del film incluye esa dimensión onírica que el propio director concedió explícitamente a las películas de Raúl Ruiz, donde el "arte de la fuga" conduce a una "liberación de la realidad por la potencia de sueño que esconde” (Sánchez, 2002, p. 217). Se trata, en efecto, de una película notable que, desconocida para el gran público, fue rodada en 1982 por un director que, contrario al cine hollywoodiense y a su hipnótica influencia, procede según un tratamiento fílmico preciso y refinado cuyas apuestas domina a la perfección (Sánchez, 1979, 1987, 2006-07). De este modo, la película es tanto más ejemplar en la medida que constituye la primera vez en que su autor -cuya filmografía no es muy larga - lle- 
va a cabo, de forma plenamente desplegada y lograda, su particular uso de los medios cinematográficos. Pero nuestro interés por el film, lejos de limitarse únicamente a sus procedimientos, también se enfoca en su contenido que, a pesar de primeras impresiones, concierne la época oscura en la cual fue rodada, es decir, la dictadura cívico-militar de Pinochet.

Los deseos concebidos cuenta la historia de R., un adolescente que decide abrirse a la vida con todo. Vive con su hermana en casa de sus tíos y, en el liceo, se encuentra al borde del fracaso escolar. Pasa su tiempo fumando marihuana y frecuenta un grupo de compañeros constantemente vigilado por el supervisor de la escuela. Su hermana ha decidido partir a vivir con su pareja, dejando solo a su hermano que, desamparado, también abandona la casa de sus tíos para errar de un albergue a otro. Ayudado por Mansilla, el guardia nocturno del liceo, R. aloja en su escuela, pero es pillado copiando en una prueba junto a sus amigos. El director de la escuela deja a todos los demás, excepto a él, libres de cargos y, por lo tanto, es sólo K. quien recibe el castigo. A su vez, Mansilla es despedido de su trabajo y lleva al joven a dormir a su casa, donde vive con su esposa e hija. Éstas últimas, en mitad de la noche, se cuelan en la habitación de R. y se recuestan a ambos lados de él. Pocos días después, la esposa de Mansilla lo regaña por no tener trabajo y expulsa a su marido de la casa.

Entonces, R. y Mansilla se instalan en casa de Alfonso, uno de los compañeros de liceo del primero. Inmediatamente, se establece un coqueteo erótico muy singular entre segundo y la madre de Alonso. Por su lado, R. ocupa la habitación de Catalina, prima de Alfonso, la cual ingresa desnuda, durante la noche, a la cama junto a R. Entre ambos se establece una relación amorosa, pero Alfonso había también tenido un romance con Catalina y se pone celoso. Los dos amigos se disputan a golpes, mientras sus peleas se mezclan con otras riñas en las que $\mathrm{R}$ y sus amigos luchan por un mimeógrafo con otra pandilla de estudiantes, los cuales provienen de medios más acomodados.

Catalina y Alfonso vuelven a estar juntos. R. se encuentra nuevamente solo y toma la decisión de marcharse. Mansilla se disculpa con la madre de Alfonso: no hizo bien su trabajo y, en vista de ello, se va igualmente. Enseguida, en el liceo, el protagonista encuentra a su profesora de filosofía, quién lo invita a quedarse en su casa. Allí, R. cena con la maestra y su marido. Este último pronuncia un largo discurso sobre el derecho reservado a una elite de hombres tanto para satisfacer sus vicios como para cultivar las formas más delicadas de enriquecerlos. El hombre parte a descansar y su esposa propone a R. ir a acostarse juntos. Van, entonces, a una habitación. El marido los espía con lujuria, mientras el ama de llaves le aprieta el cuello con una cuerda. R. no logra quitarle el sostén a su improvisada amante. El marido protesta por la inexperiencia del joven y el ama de llaves sigue estrangulando a su jefe hasta darle muerte en pleno éxtasis.

Por la mañana, R. se esconde en el ataúd del muerto, huye de la casa y se encuentra con Mansilla en casa de Moro, otro compañero de liceo. La madre de éste los recibe, haciendo notar su interés por la limpieza y por el orden. En el nuevo hospedaje, hay una joven vestida de uniforme escolar que cuida de un ciego, el cual la controla estrictamente. De nuevo, Mansilla coquetea con la dueña de casa. Esta vez ninguna mujer se mete en la cama de $R$, pero la joven de la casa se muestra interesada en él y, sin tomar la iniciativa, permanece en un coqueteo inocente, dejándose desear. Mansilla se siente atraído por ella y le ofrece irse juntos. La joven guarda silencio.

Enseguida, Mansilla, Moro, R. y otros montan una estafa: con el mimeógrafo, pretenden falsificar billetes. La banda se reúne, planifica, discute sus éxitos: hablan como si se tratase de un negocio. Mansilla conspira contra R. y propone a los otros dejarlo fuera del golpe. De este modo, habría menos gente para compartir las ganancias. Los restantes miembros de la banda se resisten, mientras que R. continúa su coqueteo con la bella escolar $y$, finalmente, toma la iniciativa: los dos jóvenes se besan.

Entonces, Mansilla traiciona a todos. Se escapa con el botín, secuestra a la joven y huye. R. y sus compañeros lo persiguen, pero Mansilla logra escapar. La banda regresa a casa, donde un grupo de gánsters armados los espera. Hay un tiroteo en el cual, a excepción de R., todos mueren. Uno de los matones sobrevive y, herido, escapa. R. busca a Mansilla y la joven por toda la ciudad. No puede encontrarlos. Está de camino a un motel. En la radio, escuchamos una canción romántica: "Suspiro" de Salvatore Adamo. Las parejas duermen juntas y de repente se oyen dos disparos. Mansilla le disparó a la chica y se suicidó. R. llega a la habitación y encuentra a la joven herida de muerte. Le acaricia la mano y la besa. Su voz en off dice: "No pudo resistirse. Poco a poco, se soltó, se resbaló... Me di cuenta de que la amaba y la abracé para que muriera."

El protagonista se duerme y, luego, despierta. "Cuando me desperté - continúa la voz en off - recordé lo que pasó como si fuera un sueño." Él besa a la joven muerta y se va. Sale a la calle. Por primera vez, vemos la ciudad. 
Es temprano en la mañana y los autos están empezando a rodar. Circula $\mathrm{R}$. por una calle casi vacía donde hay un letrero luminoso que dice: “Chile”.

\section{La sujeción al deseo}

A partir de esta historia, podemos adivinar que la película trata sobre las derivas de la sujeción de un joven al deseo, cuyas singularidades están indicadas por numerosas pistas encontradas tanto formal como diegéticamente. Ciertamente, que concierna asuntos del deseo, ello es ya suficientemente evidente por el título mismo del film que, además, se integra a un proyecto más amplio del director en orden a realizar una trilogía del deseo, de la cual Los deseos concebidos constituye la primera entrega. ${ }^{10}$ Sin embargo, en este título, los deseos en cuestión se denotan concebidos sin que, por ello, se pueda realmente saber quién los concibe ni en relación a quién son ellos concebidos. El deseo se señala, entonces, en conformidad con un equívoco, el cual es incluso redoblado por un juego de palabras. Pues, el vocablo concebidos, cuando se lo articula a deseos, reenvía inmediatamente al termino concedidos que únicamente discrepa del primero por una exclusiva letra: una $b$ en lugar de una $d$. De este modo, el título de la película comporta una suerte de lapsus que, reducido al mínimo diferencial de un signo, se expresa a la manera de una dislexia o, mejor dicho, de una disgrafía donde, por cierto, resultan evocadas las dificultades escolares del protagonista, cuyo nombre se encuentra igualmente resumido a su sola inicial: “R.”.

\section{$\frac{\text { Concebidos }}{\text { Concedidos }} \frac{b}{d} \frac{R}{\text { (que yo) erre }}$}

Sustitución mínima, entonces, limitada a una letra que, en el mismo campo del deseo, sitúa la concepción en el lugar de la concesión reprimida, cuya represión sólo acontece en nombre de la frase que compone: los deseos concedidos. Esta última es, en efecto, un giro bastante más común que el primero, el cual en modo alguno representa un enunciado habitual y constituye, incluso, una expresión algo forzada. Pero, sobre todo, se trata de una fórmula que, amparando la misma ambigüedad que la primera, contiene aún más equívocos. Es, de hecho, la expresión exacta que el conocido cuento infantil atribuye al genio de la lámpara. Ante los anhelos de su amo, éste le concede sus deseos. Esto puede parecer extraño en francés, pero no en español, donde el verbo "conceder" expresa tanto la acción de satisfacer (es decir, cumplir, complacer, contentar) como el acto de conceder (dar, acordar, otorgar, ceder). Así, la frase mantiene la misma imprecisión que la anterior y, al igual que en ella, no consigue precisar quién concede, ni a quién se concede, salvo que en ésta se intensifica aún más el equívoco, toda vez que quién concede el deseo, como es el caso del genio, se concede a aquel deseo y, por ello, concede su deseo al deseo que concede. En otras palabras, por su concesión, él y su deseo devienen objetos del deseo del Otro, alienados en el deseo del Otro.

De eso se trata exactamente la película. El protagonista se encuentra, cada vez, sujeto al deseo del Otro. En efecto, en todos los lugares donde R. duerme (y donde se acuesta), es siempre objeto del deseo del Otro: la mujer y la hija de Mansilla se meten en su cama; Catalina aparece desnuda bajo sus sábanas y, sin que él haga estrictamente nada, le dice “¡eres terrible!”; la profesora de filosofía y su marido se sirven de él para llevar a cabo la escena voyerista. Paralelamente, en cada casa, él asiste a la satisfacción sexual de los adultos en circunstancias donde espía al modo de un voyeur, pero sin excitación. Estas escenas son a veces bastante extrañas, es decir, le resultan extranjeras, como en el caso ejemplar de los encuentros nocturnos de Mansilla y la madre Alfonso, quienes recurren a pies y zapatos de manera un tanto fetichista, además de establecer relaciones con connotación sadomasoquista donde él queda inmóvil con dos piedras en las manos, mientras ella camina sonámbula.
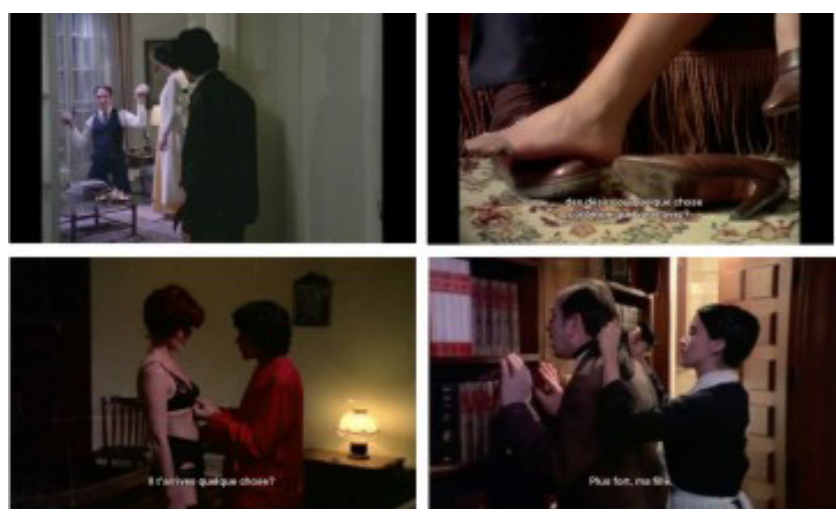

C. Sánchez, Los deseos concebidos, 1982

De hecho, sólo en tres ocasiones el protagonista se muestra actuado por su deseo: al principio, cuando escribe en un cuaderno su desesperación por abrirse a la vida con todas sus fuerzas; un poco más adelante, cuando secretamente ve a su hermana desnudarse y, culpable, siente que algo se había roto entre ellos; $y$, al final, 
cuando luego de decidir comprometerse con la joven, se da cuenta que la amaba y que ella estaba muriendo. Significativamente, estos tres pasajes están marcados, muy precisamente, por la aparición del relato de R. en voz en off. Cabe destacar que la película sólo utiliza dicho recurso fílmico para estos tres momentos específicos. Básicamente, el uso del procedimiento técnico parece representar una indicación, en el plano formal, de la inflexión producida en el protagonista relativa a una subjetivación del deseo donde R. da fugazmente lugar en el decir (subjuntivo) al deseo que yo erre.

En tal sentido, cabe observar con mayor precisión que lo que, en la película, es capturado por el deseo del Otro, no es tanto el sujeto devenido puro objeto para el Otro, sino más bien el deseo del sujeto alienado al deseo del Otro. Así, los deseos concebidos del film no son sólo los deseos que el Otro concibe respecto al sujeto tomado como mero objeto de sus caprichos, sino los deseos concebidos por el sujeto según los deseos que concibe en el lugar del Otro. Sin embargo, por cuento esta concepción del deseo viene a subrogar la represión de la concesión del deseo, el sujeto únicamente concibe los deseos del Otro al concederle los deseos y, en ello, concederle también su propio deseo. Dicho de otro modo, la película retrata el trayecto del protagonista en relación al deseo, exponiendo su tránsito que, pasando por la culpa, va desde la exasperación a la asunción y que, para ello, debe enfrentar su alienación en el deseo del Otro donde es arrojado a la errancia.

De hecho, esta errancia del sujeto en el deseo o, mejor dicho, la errancia del deseo en el deseo, se encuentra inmediatamente indicada por el nombre del protagonista. Tanto en español como en francés (el director es también francófono), la letra $R$. evoca el errar del yerro donde ello erra. Pero la errancia se aprecia igualmente articulada en la arquitectura misma del film. En efecto, éste procede por una disolución de la trama central que, privada de una unificación completa, se disemina rizomáticamente en múltiples argumentos secundarios. Conectados, estos últimos repiten de manera diferente y desplazada el mismo motivo para configurar una trayectoria compuesta por la sucesión de una "serie de anamorfosis" al modo en que, según Deuleuze (1985, p. 77), lo haría precisamente el sueño.

Se trata, por lo demás, de un rasgo del cine de Sánchez que Aburto Arenas (2006-07) ya había agudamente captado en relación con el ejercicio de una aproximación fílmica a lo real que, en y a través de las imágenes, huye siempre fuera de lo visible. En tal sentido, Jorge
Ruffinelli (2006-07) destaca el carácter nómada que, en el conjunto de la cinematografía del director, introduce la persistencia del "fuera de lugar" de los personajes, las situaciones, las acciones e, incluso, de las películas en cuanto tales. Sin ir más lejos, el mismo Sánchez (2006-07) no sólo constata la errancia de sus héroes arrastrados "a extraños devenires" bajo la influencia de "fuerzas que los desposeen" y "los empujan hacia un Afuera", sino también subraya la deriva de su propio tratamiento fílmico que, "por un desdoblamiento del lenguaje", sigue "un camino lateral o serie discontinua" (p. 159).

En definitiva, se trata de una composición, tanto formal como diegética, inspirada en el cine de Ruiz, del cual Sánchez (1990b) remarca su "imagen tiempo barroca, constituida por pliegues, repliegues y despliegues" conforme a un "método rizomático" en el que los múltiples desvíos, ramificaciones y "proliferación de objetos, luz, decorados, personas" buscan captar "la singular diferencia que los atraviesa en su continuo e ilimitado descentramiento" (p. 140-1). Pese a ello, el cine de Sánchez no muestra aquel barroquismo característico de las películas de Ruiz y, muy por el contrario, sus obras se sirven de un minimalismo que disminuye toda hipérbole, y donde la multiplicidad jamás es despliegue sino más bien pliegue.

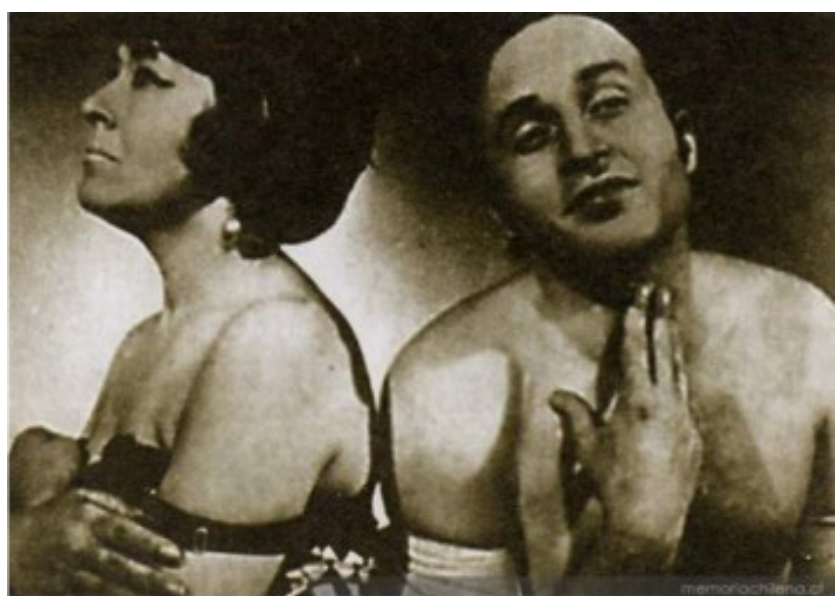

R. Ruiz, Los tres tristes tigres, 1968

Esta sobriedad casi algebraica del errar del deseo en el deseo del Otro hace recordar Teorema de Pasolini (1968). De hecho, la escena voyerista con la profesora de filosofía y su marido no parece del todo lejana de Salo o los 120 días de Sodoma (Pasolini, 1975). Aunque, a diferencia de ésta última cinta, en el film de Sánchez el deseo permanece, como en Teorema, por entero irrealizado. 


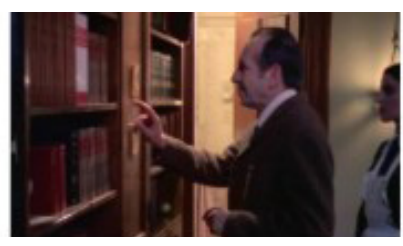

C. Sánchez, Los deseos concebidos, 1982
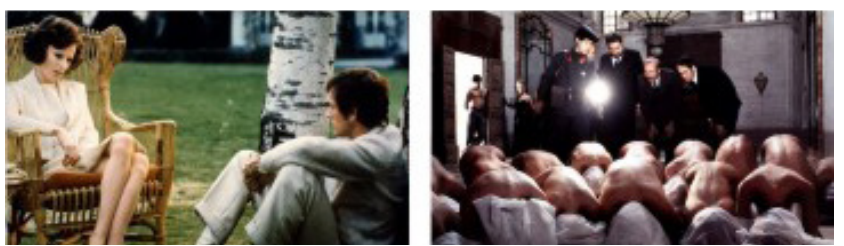

P. P. Passolini, Teorema, 1968

P. P. Passolini, Saló o los 120 días de Sodoma, 1975

En todo caso, el deseo insatisfecho no se limita a esta sólo escena y se extiende por todas partes en la película de Sánchez: la hija y la esposa de Mansilla se meten en la cama de R., sin embargo nada más sucede; Catalina aparece desnuda junto a R. y, pese a besarse, nada más ocurre entre ellos, mientras ella decide volver con Alfonso; R. se deja llevar por su deseo hacia la joven escolar pero, cuando él se resuelve a tomar la iniciativa, ella es secuestrada y luego asesinada. Ningún pasaje del film permite que la realización del deseo se infiltre. No obstante, ello en modo alguno implica que el deseo jamás se cumpla. El cumplimiento del deseo poco tiene que ver con su realización. Pues arrojado, en tanto concedido, a su deriva en el deseo concebido por el Otro, el deseo no se cumple por su realización en algo otro. Su cumplimiento únicamente adviene en su despliegue por el deseo. ${ }^{11}$ Así, al final de la película, el deseo de R. viaja por la ciudad, aunque esta vez menos como errancia y alienación, sino más bien al modo de una deriva abrazada, es decir, como apertura del deseo a su deseo.
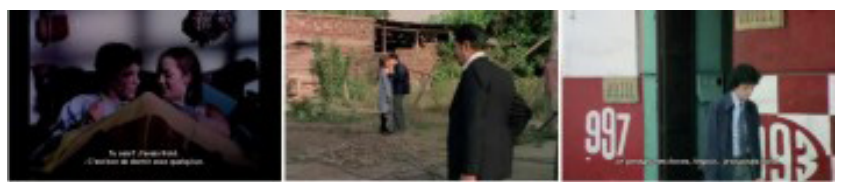

C. Sánchez, Los deseos concebidos, 1982

\section{El deseo insatisfecho}

En este sentido, la película de Sánchez retoma el motivo del deseo inacabado que el propio director (Sánchez, 1984, 1990) reconoce, por cierto, en el cine de Buñuel. De hecho, la antes mencionada escena voyerista tiene, incluso en su tratamiento del color, una apariencia muy buñueliana. Hay igualmente otros pasajes en los cuales el rea- lizador procede, como él mismo lo observa a propósito del lugar de las anomalías en Buñuel (Sánchez, 2002), a la inclusión de objetos o situaciones totalmente descentradas y que, a pesar de su disonancia con el contexto, no producen ninguna extrañeza, como si no hubiera nada inusual en ello. Pero, al igual que en el caso de Ruiz, Sánchez lleva el naturalismo aún más lejos $\mathrm{y}$, a través de una desdramatización fundamental de la interpretación de los actores (los cuales son, en su mayoría, actores no profesionales), opera una especie de pliegue que, mezclado con cierta circunspección, aleja su película de todo el onirismo y del melodrama típicamente presentes en la obra de Buñuel.

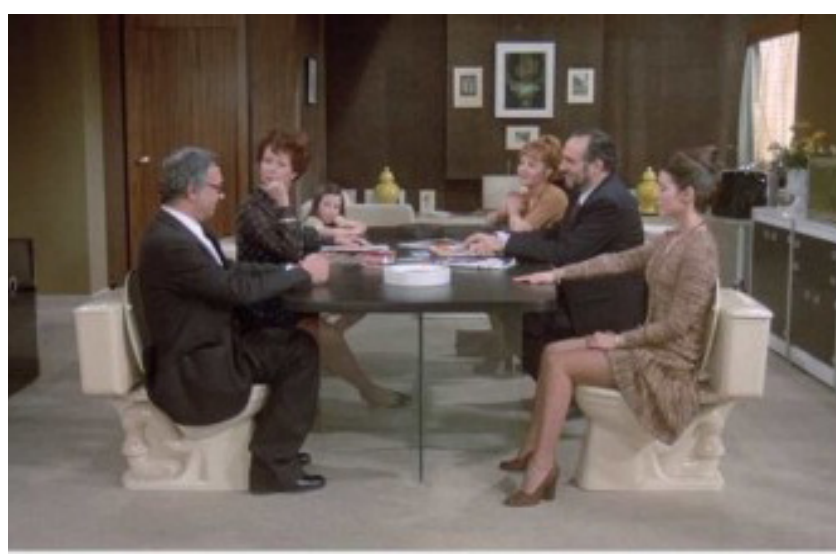

L. Buñuel, Le charme discret de la bourgoisie, 1975

Esta especie de aplanamiento cinematográfico, suerte de reducción o minimalización fílmica, es el resultado de un tratamiento de las imágenes que el director toma prestado de un tercer realizador, del cual sin duda se inspira: Robert Bresson. El recogimiento dramático de los personajes, cuyas afectaciones se derivan únicamente de sus acciones, constituye claramente un expediente que, como la ausencia de psicologismo, la platitud del espacio, la importancia del montaje sonoro o el ritmo de los planos, conecta los procedimiento de su película con el cinematógrafo bressoniano. De hecho, cuando examina el cine de Bresson, Sánchez (2006-07b) destaca en él las operaciones fílmicas que tienen igualmente lugar en su propio trabajo: el drástico recorte de un fragmento de real desprovisto de sus coordenadas habituales, así como el aplanamiento de las tomas y el despojo de su significación con el fin de amplificar la capacidad relativa de la imagen para conectarse y transformarse por su encuentro con otras imágenes. No obstante, también aquí el director chileno agrega nuevamente singularidades que, combinadas con su particular uso de los expedientes ruizianos y buñuelianos, lo alejan igualmente del gran (quizás el más grande) realizador francés. 


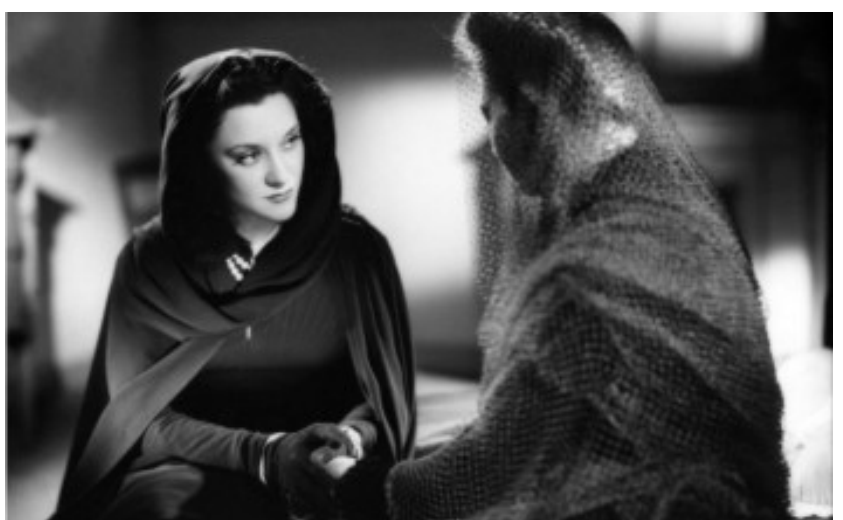

R. Bresson, Les dames du Bois de Bologne, 1945

En definitiva, Los deseos concebidos muestra bien la implementación de un tratamiento fílmico de las imágenes, con imágenes, por imágenes y entre imágenes, donde montaje, encuadre, composición de planos, sonido, personajes, acciones, narrativa, nombres, textos $\mathrm{y}$, en general, el conjunto de medios cinematográficos se articulan en un trabajo del film. Como Kuntzel $(1972,1975)$ lo señaló con precisión, éste último procede conforme a operaciones ciertamente equivalentes, e incluso a veces idénticas o casi idénticas, de aquellas que Freud (1900) pudo reconocer en tanto trabajo del sueño. Pero dicha comunidad de expedientes no hace del film un sueño ni, menos aún, el inverso del sueño. La película de Sánchez no contiene sueños ni tampoco representa en sí misma un sueño. Ella huye incluso de todo onirismo mediante un naturalismo desprovisto de todo ilusionismo, sin amparar ningún irrealismo ni el más mínimo ilogicismo. Sin embargo, ello no le impide dar lugar a lo inesperado ni a lo irreal, los cuales, lejos de entrañar un divorcio de toda realidad, conciernen un real aún más real que la realidad misma. (Lacan, 1968).

En tal sentido, se podría decir que el director sostiene un realismo radical que, por el trabajo del film, desrealiza la realidad hipnótica compartida en la pantalla. Así, al final de la película, R. dice tener la impresión de despertar de un sueño $\mathrm{y}$, sin ningún tipo de exasperación, sale a la calle para finalmente cumplir con el propósito que él mismo se había planteado al comienzo: abrirse a la vida con todo su corazón. Con ello, el film parece simular un happy ending, donde la realización final descartaría el sueño para consumar la hipnosis. No obstante, el deseo no se cumple por su realización, sino por su deriva que, en una suerte de empuje-a-lo- real, plantea más bien el cumplimiento del deseo, su deseo en el deseo, que subvierte la hipnosis holliwoodense.

Podríamos, sin duda, prolongar el análisis de la película y precisar aún más este deseo que numerosas coor- denadas lo indican como masculino. Podríamos observar, por ejemplo, que la errancia de R. se gatilla tanto con la traición de su hermana como con aquella que él mismo siente haber cometido hacia ella al espiarla desnuda. Traición, en cualquier caso, que deja a R. en el abandono y que se repite en cada episodio para dejar al protagonista presa de la soledad, de la cual se dice que toma su fuerza del sufrimiento cuando se es joven y del deseo cuando se es viejo. También podríamos señalar que son siempre mujeres quienes se emparan del deseo y ello diferentemente según si se trata de madres o si es el caso de jóvenes. Del mismo modo, podriamos subrayar el carácter turbio que todos los hombres adultos tienen en la película, así como la condición caída e, incluso, irrisoria del conjunto de figuras paternas. Y, por tratarse del deseo masculino en la adolescencia, podríamos incluso considerar estos diversos elementos en relación con la tragedia satírica de Frank Wedekind (1891), El despertar de la primavera, a la luz de los comentarios realizados tanto por Freud (Nunberg \& Federn, 1962) como por Lacan (1974) respecto de ella.

\section{Rastros del Terror}

En todo caso, la deriva en el deseo de R. no acontece en abstracto con prescindencia de la historia y el territorio. En efecto, entre los intersticios de sus imágenes, el film registra los rastros de una realidad que, pese a ser omnipresente, permanece a primera vista invisible en la película. Muy concretamente, ella concierne la dictadura de Pinochet, la cual invade toda la cinta mediante sutiles detalles que dejan la marca oscura de una atmósfera abrumadora bastante sensible en varias escenas. Por cierto, la mayoría de los comentarios dedicados al cine de Sánchez coinciden en observar, de diversas formas, este dominio dictatorial, aunque no por ello se logra captar del todo su alcance ni darle un lugar más preciso. Así, Plaza (2004) señala la alusión que se hace a la dictadura en la confrontación vertical entre los jóvenes y su Liceo, pero la indicación se detiene allí y, literalmente, ocupa el espacio de una sola línea. Por su parte, Aburto Arenas (2006-07) sólo destina una nota a pie de página para identificar las sirenas de alarma en tanto evocación de una ciudad sometida a la hipervigilancia policial. A su vez, Cavallo (1999) destaca cuanto la situación dictatorial de la época permitiría una lectura política del film, la cual sería no obstante, mucho menos interesante, en su opinión, que aproximaciones antropológicas o estéticas a la película. Únicamente Ruffinelli (2006-07) concede un lugar decisivo al impacto de la dictadura, la cual 
incide sobre el conjunto de la obra de Sánchez que, confrontado a la amenaza del Terror y el Estado de excepción, habría desarrollado un particular lenguaje cinematográfico atravesado por el "fuera de lugar" y el descentramiento nómada. Pero si seguimos su examen, aún cuando no se trate según él de una pura coyuntura, aquellos oscuros años de plomo sólo entrarían en la película a través de atmósferas contextuales propicias para motivos retorcidos. No obstante, la dictadura se encuentra presente de manera bastante más directa en el film, cuya condición política alertó, en su momento, a la policía secreta de Pinochet que, como lo relata Sánchez (Ruffinelli, 2006-07b), llegó al plató durante el rodaje para arrestar y, luego, interrogar a dos actrices del equipo. Por lo demás, tiempo después, el propio dictador pidió que se entregara una copia de la película para visionarla en privado.

Demos un vistazo a algunos de estos rastros, a veces muy fugaces, de aquel sombrío período de la historia chilena. En primer lugar, cabe señalar la observación permanente a la que son sometidos los estudiantes por parte del supervisor del Liceo, quién llega incluso a husmear en sus ropas a la manera de un policía. De modo más general, los jóvenes son en todo momento sospechosos, lo cual evoca dos circunstancias propias de aquellos tiempos de dictadura: por un lado, a la figura legal de la detención por sospecha que permitía a la policía arrestar a una persona (en su mayoría jóvenes) por el mero hecho de parecerle sospechosa; y, por otro lado, el cambio ocurrido, durante la dictadura, en los atributos conferidos a la juventud que, habiendo previamente sido la esperanza de la sociedad, se encontraba en vías de ser mudada en una de las figuras antisociales por antonomasia (drogadictos, viciosos, transgresores, subversivos). Pero, en la película, la vigilancia se extiende aún más allá y todo el mundo espía a todo el mundo, evocando la desconfianza general sembrada por la dictadura en razón del miedo a ser denunciado ante las autoridades o a ser arrestado por la policía secreta. La acción de esta última es también aludida en la escena donde los miembros de la banda R. son asesinados por unos gánsteres que, sugerentemente, van vestidos a la usanza de los agentes de la policía secreta y que, además, conducen un Peugeot 504, es decir, uno de los automóviles más utilizados en la época por estos siniestros funcionarios.
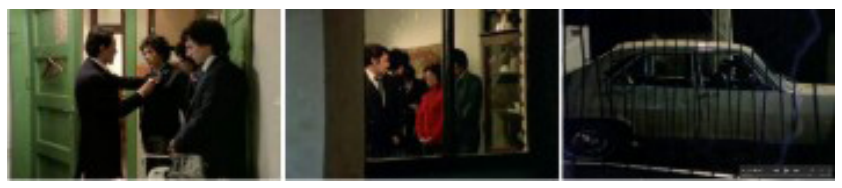

C. Sánchez, Los deseos concebidos, 1982
Otro elemento indicativo de la dictadura en la película es la disputa que, por el mimeógrafo, enfrenta a dos grupos muy distintos de jóvenes. Uno reúnen estudiantes cuyas pieles resultan ser más blancas, de cabellos claros y cortados a lo Principito, con acento fuertemente oclusivo y vestimentas bien cuidadas, es decir, un grupo de clase acomodada y conformado al orden. En cuanto al otro, aquel de R. y sus amigos, está integrado por secundarios menos favorecidos, de piel morena, cabellos negros, ropa desarreglada y hábitos más transgresores. Se trata, por cierto, de una diferencia de clase social, pero también de una diferencia en el favor otorgado a unos y a otros por la autoridad del Liceo. Es, en el fondo, una disputa que fácilmente evoca la profunda división introducida por la dictadura en la sociedad chilena, lo cual resulta reforzado por el mimeógrafo que, en aquella época, constituía un valioso instrumento de resistencia, toda vez que utilizaba para la confección de los panfletos que se lanzaban a la calle durante las manifestaciones.
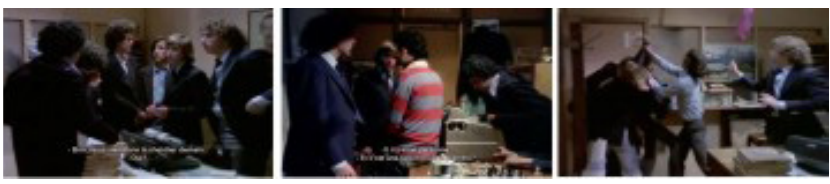

C. Sánchez, Los deseos concebidos, 1982

Además, el director del Liceo sostiene explícitamente propósitos casi idénticos de expresiones del mismo $\mathrm{Pi}$ nochet: "Necesitan una mano firme, una mano dura, una autoridad... -dice, por ejemplo, a los estudiantes. Que los hiciera respetar el orden, el aseo, la higiene. [Estos son valores]. En el sentido moral de la palabra”. De hecho, se tratan de valores que, gravitando fuertemente en la disciplina militar, integraron el proyecto definitivamente higienista que, con sus diversas metáforas biológicas, impulsó el poder dictatorial y el propio dictador (Leyton, 2015), Comandante en Jefe del Ejército de Chile, como si la ordenanza o el llamado al orden pudiesen preservar el orden de acuerdo a sus órdenes.

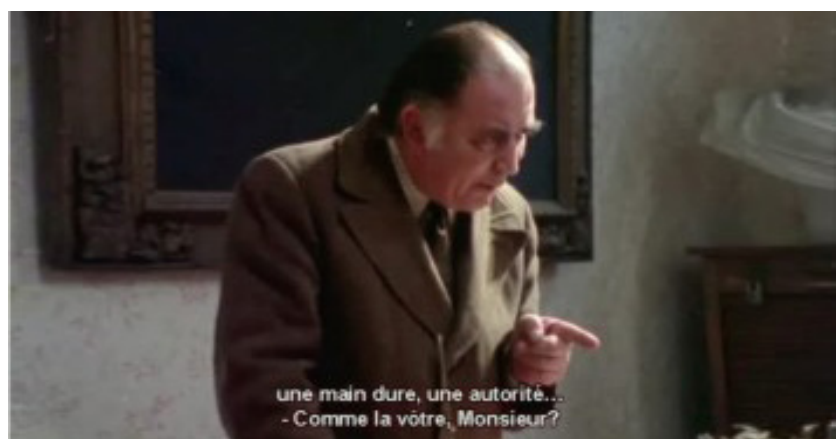

C. Sánchez, Los deseos concebidos, 1982 
Los propósitos del director del Liceo llegan, incluso, a imponer a $\mathrm{R}$. una sanción tan caprichosa como elocuente. Ya que R. se burla de las reglas y no muestra por ellas ningún respeto, dice el director, entonces será castigado con su suspensión por el resto del año, aunque se le concede la gracia de continuar asistiendo a clases, de hacer las tareas y de rendir los exámenes. No obstante, R. será borrado de todos los registros del Liceo, es decir, añade el director: "Estás legalmente muerto". Como señala el propio Sánchez, ${ }^{12}$ se trata de una sentencia por la cual se hace referencia a la absurda ley burocrática que aparece en El proceso de Kafka (1925), donde el protagonista porta, como R., un nombre reducido a una sola letra: "K.”.

Sin embargo, el castigo muestra igualmente un curioso aspecto que no puede dejar de evocar la más grosera coartada que, para negar su máquina asesina, esgrimió en aquel entonces la dictadura cuando, con la connivencia del poder judicial, argumentaba que un desaparecido no había muerto, es decir, no había sido asesinado, pues no había ningún cuerpo que pudiese legalmente establecer su muerte y que, por lo tanto, seguramente aún vivía en otro lugar. En tal sentido, respecto a los desaparecidos, la dictadura recurrió a los mismos términos que el director del Liceo utiliza para castigar a R. Ciertamente, los términos no se articulan de manera idéntica en ambos casos, no obstante la articulación usada para los desaparecido es, de hecho, el opuesto perfecto de la articulación empleada para R. Por lo demás, para uno y otros, el resultado es ciertamente similar, toda vez que aquí y allá confiere a cada quién la misma condición paradójica de estar muerto aunque aún en vida. En todo caso, en lo que respecta a los desaparecidos, la muerte sólo era un asunto de registros que los agentes del Estado se habían ocupado de suprimir, además de eliminar de todo documento a los asesinados y, en un número nada despreciable de casos, llegar incluso a borrar sus huellas de toda la superficie del planeta, tirando sus cadáveres al mar o enterrándolos en hornacinas sin registro.

Por último, como presencia espectral de la dictadura en el film, se encuentra igualmente el predominio de los espacios cerrados, al interior de las casas, mientras que los pocos espacios abiertos que se muestran se encuentran todos, o casi todos, vacíos. A excepción de unos pocos personajes, nadie está presente. Por cierto, estos espacios evocan los permanentes toques de queda que, impuestos en dictadura, obligaron a los chilenos a quedarse en casa o alojar donde algún conocido hasta el día siguiente, en especial los jóvenes que, para disfrutar de una fiesta, debían permanecer durante toda la noche y esperar hasta el fin del toque de queda, en la madrugada, para regresar a sus hogares.

Pero la prevalencia de los espacios privados y del despoblamiento de los espacios públicos representa, asimismo, aquello que el Terror impuso a las formas cotidianas de vivir y ocupar el espacio. ${ }^{13} \mathrm{La}$ amenaza de los agentes de la dictadura, la consiguiente desconfianza hacia cualquiera que pudiese integrar la policía secreta o ser simplemente un soplón (y esto, incluso, sin quererlo), la propaganda dirigida, con la complicidad de la prensa oficialista, a mostrar los peligros que representaban los opositores subversivos (terroristas, ya se decía entonces): todo esto favoreció el refugio en la esfera privada, la clausura de la sociedad y el retiro del espacio público únicamente utilizado para transitar. Así, cuando en la última imagen de la película, al fin aparece la ciudad, ésta se encuentra vacía (o casi) y el panel luminoso que dice Chile se carga de ironía: he aquí Chile, un país vacío, un territorio abandonado, dejado sólo al tránsito.

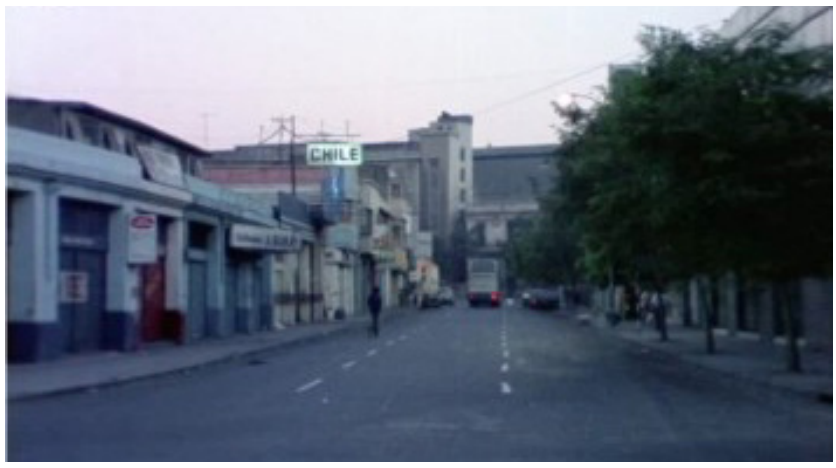

C. Sánchez, Los deseos concebidos, 1982

\section{En fin: contrariar la tiranía hipnótica.}

Únicamente incluida mediante pequeños fragmentos, la dictadura se muestra en la película bajo los efectos de la censura. Es, por cierto, bastante comprensible: la misma dictadura imponía una censura que no podía ser desafiada sin exponerse a la muerte y, por lo tanto, al mismo castigo conferido a R. Sin embargo, resulta evidente que, también y sobre todo, se trata del contexto donde, de hecho, se despliegan las errancias -las $R$. ansias- del deseo al cual ya nos referimos largamente.

En efecto, aquel deseo en el deseo no podría de ninguna manera ser extranjero a su entorno temporal y territorial. La pequeña historia de R. no es, en tal sentido, ajena a la gran historia chilena. Pues sí, al final del film, R. arriesga su deseo a la deriva del deseo en la ciudad 
vacía, aquello que está en juego no es, en el fondo, algo distinto que la subversión, mediante lo real del deseo, de la hipnosis realizada en la pantalla del Terror y montada por la dictadura en Chile. La hipnosis que, para todos los chilenos, limitaba sus deseos al espacio privado y les permitía realizarlos en toda intimidad sin realmente cumplirlos.

Pero, romper la pantalla hipnótica del terror dictatorial, la cual ronda aun y nos hace, tal como antes, adherir a la hipnosis de una realidad plagada de peligros, vulnerabilidades y riesgos. Romper, entonces, aquella pantalla hipnótica, eso se hace al modo en que R. termina por hacerlo al exponer el deseo a la deriva del deseo para, pese a los riesgos, apartar aquel deseo de su realización confinada a lo privado, para cumplirlo en el espacio político de lo social. De hecho, se trata de eso que, a nuestro parecer, hicieron precisamente, el 2016 y el 2011, jóvenes como R.: los estudiantes chilenos que se movilizaron para contrariar la pantalla que mantenía, y sigue manteniendo, a todos los chilenos magnetizados.

Desafortunadamente, el magnetizador neoliberal se recuperó demasiado rápidamente....

\section{Referencias}

Aburto Arenas, F. (2006-07). Afuera del filme: errancia, minoría y des(autor)ización en el cine de Cristián Sánchez. Nuevo texto crítico, 19-20(37-40) : 93-107; doi : 10.1353/ntc.2006.0021.

Adorno, Th. \& Horkheimer, M. (1947[1944]). Dialéctica de la ilustración. Fragmentos filosóficos. Madrid : Trotta, 1998.

Allendy, R. (1927). La valeur psychologique de l’image. In P. MacOrlan, A. Beugler, C. Dullin et R. Allendy (eds.), L'art cinématographique (pp. 75-103). Paris : Libraire Félix Alcan

Bellour, R. (2009). Le corps du cinéma : hypnoses, émotions, animalités. Paris : P.O.L..

Benjamin, W. (1955 [1939]). La obra de arte en la época de su reproductibilidad técnica. In W. Benjamin, Discursos interrumpidos $I$ (pp. 15-57). Bs. Aires : Taurus, 1989.

Boudry, J.-L. (1978). L'effet cinéma. Paris : Éditions Albatros.

Cavallo, A. (1999). El mundo secreto del secuestro. Nuevo texto crítico, 2006-07, 19-20(37-40) : 291-295; doi : 10.1353/ntc.2006.0005.

Checchia, M. (2015). Poder e política na clínica psicanalítica. Sao Paulo : Annablume.

Civitarese, G. (2013). Le rêve nécessaire. Nouvelles théories et nouvelles techniques de l'interprétation en psychanalyse. Paris : Ithaque, 2015.

Clair, R. (1951). Réflexion faite. Paris : Gallimard.

Deleuze, G. (1985). L’image-temps. Cinéma 2. Paris : Les Éditions de Minuit.

Eberwein, R. T. (1984). Film and the Dream Screen: a sleep and a forgetting. Princeton, NJ : Princeton Univ. Press.

Ehrenburg, I. (1931). La fábrica de sueños. Barcelona : Melusina, 2008.

Epstein, J. (1947). Le cinéma du diable. Paris : Melot.

Farges, J. (1975). L'image d'un corps. Communications, 23 : 88-95 ; doi : 10.3406/comm.1975.1351.

Freud, S. (1889). Reseña de August Forel, Der Hypnotismus. In S. Freud, Obras completas (vol. 1, pp. 95-110). Bs. Aires : Amorrortu, 1991.

Freud, S. (1900). La interpretación de los sueños. In S. Freud, Obras completas (vols. 4-5). Bs. Aires : Amorrortu, 1991.

Freud, S. (1921). Psicología de las masas y análisis del yo. In S. Freud, Obras completas (vol. 18, pp. 63-136). Bs. Aires : Amorrortu, 1992.

Freud, S. (1925). Lettre à Ferenczi du 14 août 1925. In S. Freud et S. Ferenczi, Correspondance 1920-1933. Les années douloureuses. Paris : Calmann- Levy, 2000.

Gabbard, G. O. (2001). Psychoanalysis and film. London, New York : Karnac.

Gay, P. (1988). Freud. Una vida de nuestro tiempo. Bs. Aires : Paidós, 1990.

Hughes, C. J. P. (1930). Dreams and films. In J. Donald, A. Friedberg et L. Marcus (eds.), Close Up 1927-1933. Cinema and modernism (pp. 260-262). Princeton, NJ : Princeton Univ. Press, 1998.

Kafka, F. (1925). El proceso. Madrid : Alianza Editorial, 2013.

Kawin, B. F. (1978). Mindscreen: Bergman, Godard, and first-person film. Princeton, NJ : Princeton Univ. Press.

Kuntzel, T. (1972). Le travail du film. Communications, 19 : 25-39; doi : 10.3406/comm.1972.1279. 
Kuntzel, T. (1975). Le travail du film, 2. Communications, 23 : 136-189; doi : 10.3406/comm.1975.1355.

Lacan, J. (1968). La psychanalyse dans ses rapports à la réalité. In J. Lacan, Autres écrits (pp. 351-59). Paris : Seuil, 2001. Lacan, J. (1974). Préface à L'éveil du printemps. In J. Lacan, Autres écrits (pp. 561-564). Paris : Seuil, 2001.

Lébovici, S. (1949). Psychanalyse et cinéma. Revue internationale de filmologie, 2(5) : 49-56.

Lechner, N. (1982). La lucha por el orden. In N. Lechner, Obras escogidas 1 (pp. 275-293). Santiago : LOM, 2006.

Lentzner, J. R. et Ross, D. R. (2005). The dreams that blister sleep : latent content and cinematic form in Mulholland Drive. American Imago, 62(1) : 101-123; doi : 10.1353/aim.2005.0016.

Leyton, C. (2015). Geopolítica y ciudad gueto: erradicaciones eugenésicas en la dictadura militar: Santiago de Chile 1973-1990. In R. Aceituno et R. Valenzuela, Golpe 2013-1973 (pp. 190-212). Santiago : El Buen Aire.

Marinelli, L. (2006). Screening wish theories : dream psychologies and early cinema. Science in context, 19: 87-110 ; doi : 10.1017/ S0269889705000773.

Martin, M. (2012). La poétique du rêve du point de vue d'une théorie des effets. Autour d'une configuration originaire. In M. Martin et L. Schifano (dirs.), Rêve et cinéma : mouvances théoriques autour d'un champ créatif (pp. 63-85). Nanterre : Presses universitaires de Paris Nanterre ; doi : 10.4000/books.pupo.3493.

Metz, C. (1975). Le film de fiction et son spectateur. Communications, 23 : 108-135; doi : 10.3406/comm.1975.1354.

Metz, C. (1977). Le signifiant imaginaire. Psychanalyse et cinéma. Paris : Bourgois, 2002.

Michel, R. (2010-11). Dumme Dinge : Freud cinéphobe ?. Savoirs et clinique, 12 : 58-68; doi : 10.3917/sc.012.0058.

Mitry, J. (1963). Esthétique et psychologie du cinéma. Paris : Editions du Cerf, 2009.

Morel, G. (2011). «This is the girl ». Sobre Mulholland Dirve (2001), de David Lynch. In G. Morel, Pantallas y sueños. Ensayos psicoanalíticos sobre la imagen en movimiento (pp. 55-75). Barcelona : Ediciones S\&P.

Morin, E. (1956). Le cinéma ou l'homme imaginaire. Essai d'anthropologie. Paris : Les éditions de Minuit, 1978.

Moulian. T. (1997). Chile actual : anatomía de un mito. Santiago : LOM, 2002.

Nunberg, H. et Federn, E. (eds.) (1962). Las reuniones de los miércoles. Actas de la Sociedad Psicoanalítica de Viena. Volumen 1: 1906-1908. Bs. Aires : Nueva Visión, 1979.

Plaza, V. (2004). Sobre Los Deseos Concebidos. Nuevo texto crítico, 2006-07, 19-20(37-40) : 297-308 ; doi : $10.1353 /$ ntc.2006.0012.

Radiszcz, E. (2005). Corte del ojo y montaje de la mirada. Anotaciones sobre «Un perro andaluz » de Luis Buñuel. Actualidad Psicológica, Enero, 4(32) : 2-7.

Rancière, J. (2003). Le destin des images. Paris : La Fabrique.

Rodriguez, A. (1983). Cómo gobernar las ciudades o principados que se regían por sus propias leyes antes de ser ocupados. In A. Rodriguez et P. Rodriguez (eds.), Santiago, una ciudad neoliberal (pp. 81-109). Quito : OLACCHI, 2009.

Ruffinelli, J. (2006-07). El cine nómada: el «fuera de lugar » en la obra de Cristián Sánchez. Nuevo texto crítico, 19-20(37-40) : 15-42 ; doi : 10.1353/ntc.2006.0007.

Ruffinelli, J. (2006-07b). El deseo de desear: diálogo con Cristián Sánchez. Nuevo texto crítico, 19-20(37-40) : 43-91; doi : 10.1353/ ntc.2006.0014.

Saalschutz, L. (1929). The film in its relation to the unconscious. In J. Donald, A. Friedberg et L. Marcus (eds.), Close Up 1927-1933. Cinema and modernism (pp. 256-260). Princeton, NJ : Princeton University Press, 1998.

Sachs, H. (1928). Film psychology. In J. Donald, A. Friedberg et L. Marcus (eds.), Close Up 1927-1933. Cinema and modernism (pp. 252-254). Princeton, NJ : Princeton Univ. Press, 1998.

Sánchez, C. (1979). El trabajo del filme. Nuevo texto crítico, 2006-07, 19-20(37-40) : 225-228 ; doi : 10.1353/ntc.2006.0010

Sánchez, C. (1984). Ese oscuro objeto del deseo. Nuevo texto crítico, 2006-07, 19-20(37-40) : 125-128; doi : 10.1353/ntc.2006.0018. Sánchez, C. (1987). Pourquoi filmez vous? Nuevo texto crítico, 19-20(37-40) : 223-224; doi : 10.1353/ntc.2006.0003.

Sánchez, C. (1990). El discreto encanto de la burguesía. Nuevo texto crítico, 2006-07, 19-20(37-40) : 133-135 ; doi : 10.1353/ ntc. 2006.0002 .

Sánchez, C. (1990b). Las tres coronas del marinero. Nuevo texto crítico, 2006-07, 19-20(37-40): 139-141; doi : 10.1353/ntc.2006.0023. Sánchez, C. (2002). El cine de Raúl Ruiz : el progreso del tiempo. Nuevo texto crítico, 2006-07, 19-20(37-40) : 213-218; doi : 10.1353/ ntc. 2006.0034 .

Sánchez, C. (2002). La misteriosa transparencia de Buñuel. Nuevo texto crítico, 2006-07, 19-20(37-40) : 179-187 ; doi : 10.1353/ ntc. 2006.0006. 
Sánchez, C. (2006-07). Aspectos fundamentales de mi cine. Nuevo texto crítico, 19-20(37-40) : 159-161; doi : 10.1353/ntc.2006.0037; Sánchez, C. (2006-07b). El viento sopla a favor de Bresson. Nuevo texto crítico, 2006-07, 19-20(37-40) : 163-178; doi : 10.1353/ ntc. 2006.0045 .

Wedeking, F. (1891). L'éveil du printemps. Tragedie enfantine. Paris : Gallimard, 1983.

Wittgenstein, L. (1953). Investigaciones filosóficas. Madrid : Trotta, 2017.

Wittgenstein, L. (1980). Observaciones sobre la filosofía de la psicología. México DF : Instituto de Investigaciones filosóficas UNAM, 2007.

\section{Références filmiques}

Bergman, I. (dir.) et Ekelund, A. (prod.) (1957). Smultronstället [film, 35mm, b/n, 91 min]. Suède : Svensk Filmindustri.

Buñuel, L. (dir.) et Amérigo, F. (prod.) (1950). Los olvidados [film, 35mm, b/n, 85 min]. Méxique : Ultramar Films.

Buñuel, L. (dir.) et prod.) (1929). Un chien andalou [film, 35mm, n/b, 17 min]. France : Les Grands Films Classiques.

Hitchcock, A. (dir.) et Selznick (prod.), (1945). Speelbaum [film, 35mm, n/b, 111 min]. USA : Selznick International Pictures.

Lynch, D. (dir.) et Edelman, P. (prod.) (2001). Mulbolland Drive [film, 35mm, couleur, 147 min]. USA : The Picture Factory.

Méliès, G. (dir. et prod.) (1903). Le rêve du maître de ballet [film, 35mm, b/n, 2 min]. France : Star-Film.

Méliès, G. (dir. et prod.) (1904). Le rêve de l’horloger [film, 35mm, b/n, 2 min]. France : Star-Film.

Pabst, G.W. (dir.) et Neumann, H (prod.) (1926). Geheimnisse einer Seele [film, b/n, 35mm, 97min]. Alemagne : Neumann-Filmproduktion.

Pasolini, P. P. (dir.) et Bolognini, M. ; Rosselinni, F. (prods.) (1968). Teorema [film, 35mm, b/n, couleur, 98 min]. Italie : Aetos Produzioni Cinematografiche.

Pasolini, P.P. (dir.) et Grimaldi, A. (1975). Salò o le 120 giornate di Sodoma [film, 35mm, couleur, 117 min]. Italie : Produzioni Europee Associate S.P.A. Rome ; Les Productions Artistes Associses S.A. Paris.

Porter, E. S. et Fleming, G. S. (dirs. et prods.) (1903). Life of an american fireman [film, 35mm, b/n, 6 min]. USA : Edison Manufacturing Company.

Porter, E. S. et MacCutcheon, W. (dirs. et prods.) (1906). The dream of a Rarebit fiend [film, $35 \mathrm{~mm}, \mathrm{~b} / \mathrm{n}, 7 \mathrm{~min}]$. USA : Edison Manufacturing Company.

Sánchez, C. (dir.) et Cahn, G. (prod.) (1982). Los deseos concebidos [film, 16mm, couleur, 128 min]. Chili : Foco Films.

Sánchez, C. (dir.) et Duque, C. (prod.) (1994). El cumplimiento del deseo [film, 16mm, couleur, 87 min]. Chili : Nomada Producciones.

Sánchez, C. (dir.) et Ferreti, P. (prod.) (2008). Tiempos Malos [film, 16mm, couleur, 140 min]. Chili : Nomada Producciones.

1 Se trata, por cierto, de aquello que Joël Farges (1975) había con acierto señalado en un texto, del cual sólo tuvimos noticia mucho tiempo después.

2 El paralelo fue, de hecho, muy tempranamente formulado, hacia fines de los años 1920, por psicoanalistas como René Allendy (1927), Hans Sachs (1928), L. Saalschutz (1929) et Pennethorne Hughes (1930).

3 Es evidentemente asunto de perspectivas que, bajo una fuerte influencia del psicoanálisis, han sido suscritas por Christian Metz (1977) o por Jean-Louis Boudry (1978). No obstante, es también el caso de los planteamientos, anteriores y bastante menos psicoanalíticos, de Edgar Morin (1956) y de Jean Mitry (1963).

4 Desde 1940, el número de aproximaciones psicoanalíticas donde se sostiene una articulación entre cine y sueño no ha cesado de crecer. Fue, por supuesto, el caso de los propósitos sostenidos por Serge Lébovici (1949), Bruce Kawin (1978) y Robert Eberwein (1984), pero es igualmente la situación de otros trabajos más recientes como varios de los textos reunidos en libro editado por Glen Gabbard (2001) e, incluso, la posición implícita en las más actuales consideraciones de Guiseppe Civitarese (2013) sobre el sueño.

5 Excepto un comentario muy fugaz de Christian Metz (1975) relativo a "las secuencias de sueños" en "films narrativos" que, siendo según él "casi siempre tan poco creíbles" (p. 121), parece haberme ampliamente servido de punto de anclaje para mi recuerdo encubridor.

6 Como Marcelo Chechia (2015) lo ha demostrado con acierto, ninguna discusión sobre la hipnosis podría divorciarse de dimensión política que ella tiene para Freud. En efecto, la crítica freudiana de la hipnosis concierne abiertamente su específica forma 
de ejercicio del poder al subrayar cuanto la "sugestión" puede implicar "la asfixia de la libre personalidad por parte del médico que [...] detenta el poder de guiar al cerebro dormido" (Freud, 1889, p. 102). Es justamente contra esta “tiranía de la sugestión” (Freud, 1921, p. 85) que, como lo destaca Checcia, Freud (1900) se inclina hacia el poder de la palabra implicada en la asociación libre que, precisamente, el sueño reclama para su interpretación (pp. 122-125).

7 Morel, G. (2011). «This is the girl». Sobre Mulholland Dirve (2001), de David Lynch. In G. Morel, Pantallas y sueños. Ensayos psicoanalíticos sobre la imagen en movimiento (pp. 55-75). Barcelona: Ediciones S\&P.

8 Aunque la sugerente reformulación, propuesta recientemente por Marie Martin (2012) con su noción de “efecto sueño", es interesante $y$, en algunos aspectos, no se aleja demasiado de nuestras propias orientaciones.

9 Para acceder a una versión en español no subtitulada de la película, se pueden visitar los sitios: http://www.arcoiris.tv/scheda/ es/1199/ y https://www.youtube.com/watch?v=F1TS6WgLC7o

10 Las otras dos películas de la trilogía son El cumplimiento del deseo (1994) y Tiempos malos (2008).

11 Por el contrario, aunque en el mismo sentido, en la segunda parte de la trilogía de Sánchez, la realización del deseo deviene precisamente la imposibilidad misma de su cumplimiento.

12 C. Sánchez, comunicación personal, 21 septiembre 2017.

13 Como lo han observado, entre otros, Norbert Lechner (1982), Alfredo Rodríguez (1983) y Tomás Moulian (1997), la violencia de Estado durante la dictadura promovió un abandono de los espacios públicos en favor del repliegue hacia el encierro familiar del hogar que, en contra de los logros de la acción colectiva durante el período de Allende, llevó a la progresiva desertificación de los lugares comunes y a la privatización generalizada de las relaciones sociales, lo cual fue ampliamente aprovechado por la máquina neoliberal para privar a la ciudad de su territorio compartido y arrancarle su esfera ciudadana gracias a las mandíbulas depredadoras del mercado inmobiliario. 